\title{
The Countermeasures Study of Joint-Equity Commercial Banks Training in the Context of Lifelong Learning
}

\author{
Jingyan Duan \\ International Business School \\ Yunnan University of Finance and Economics \\ Kunming, China \\ 20025859@qq.com
}

\begin{abstract}
Nowadays, the financial industry develops rapidly with updated knowledge constantly and banking industrial competition intensely, so lifelong learning becomes the necessary requirement for the career development of employees. Jointequity commercial banks face how to balance efficiency and effectiveness of training for employees. This article is based on methods and characteristics of the lifelong learning, and adopts interview to collect information of training efficiency and effectiveness about joint-equity commercial banks. Then, this article takes induction to summarize results of interview. Finally, it provides reasonable recommendations to improve training efficiency and effectiveness of joint-equity commercial banks.
\end{abstract}

Keywords: lifelong learning, training methods, training efficiency, training effectiveness

\section{INTRODUCTION}

Human beings are in the background of an unprecedented rapid change period, and the knowledge update period is shortened within about 3 years. A number of new knowledges, new technologies, new inventions and new creation increase rapidly, and the period from invention to application is shorter and shorter distinctly. Lifelong learning is the best way of society and enterprises to develop and keep the sustainability. Employees can gain better career development opportunities by lifelong learning. Moreover, lifelong learning enables enterprises, especially banks and other knowledge-intensive and capital-intensive enterprises, to develop their core competitiveness continuously, and win in the strong market competition.

However, most of Chinese joint-equity commercial banks have not provided necessary and effective career development training for employees. The main reason is the unreasonable training contents and methods which cause poor training efficiency. The cost control is also decreased the frequency and standard of training.

Therefore, the current issue is how to balance efficiency and effectiveness of employee training in the context of accelerating knowledge updating and intensifying market competition. On the one hand, the acceleration of knowledge update requires banks to increase the frequency of training to help employees learn more new knowledge. On the other hand, the incentive market competition requires banks to control training cost while providing training.

According to characteristics and learning methods of lifelong learning, this article collects information of training methods, effectiveness and cost from HR experts and employees of joint-equity commercial banks. Then it analyzes collected information. Finally, it provides reasonable recommendations to improve training efficiency and effectiveness of joint-equity commercial banks.

\section{CLASSIFICATION AND CHARACTERISTICS OF LIFELONG LEARNING}

The First world Lifelong Learning Conference defines lifelong learning as: lifelong learning is the survival concept in the 21 st century... It is a process of human potential finding, which encourage people to obtain the knowledge, value, skills and understanding, and be able to apply them in different tasks, situations and environments [1]. This definition point out clearly that lifelong learning is a survival concept and a survival and developmental prerequisite of the enterprise employees. Besides, the competency of the lifelong learning can impact human talent advantages, economic advantages, and the economic benefits of enterprises.

The lifelong learning includes the formal learning, the informal learning and the non-formal learning. The formal learning is also called the school degree education, which provides Bachelor Degree, Master Degree, and PHD Degree in higher education institutes.

Usually, the employee training is adopted the informal learning, because it has various learning methods and approaches, such as the short-term training courses, seminars, and online courses. Employees can decide their learning contents, places and time by themselves. 
The third form of the lifelong learning is non-formal learning, which is learned from daily lives. For example, people learn how to use new products and equipments from this method. Non-formal learning is an individual self-study method. Learners can decide their interested contents and majors, and study in various approaches and self-control study pace to achieve their learning targets and satisfy their individual needs in both work and personal lives.

Therefore, the characteristics of informal learning and nonformal learning meet the requirements of joint-equity commercial banks staff training. However, these two learning methods are not easy to achieve satisfactory effectiveness. HRM of joint-equity commercial banks need to analyze current training problems, and then help employees the staff to form the consciousness of lifelong learning and habits.

\section{TRAINING ISSUES OF JOINT-EQUITY COMMERCIAL BANKS}

With the rapid development of the financial industry, the competition of the banking industry increases more and more fierce, and it also develops as the competition of human talents. Obviously, the high-quality human talent is the core competitiveness of joint-equity commercial banks. Training refers that organizations adopt various training programs to improve knowledge, skills, abilities, and work performance of employees. The purpose of training not only improve employees' competencies and meet job requirements, but also improve the performance of individuals and corporates.

For finding problems of the training of joint-equity commercial banks, researchers followed questions of Table 1 to get information of training from HR experts and managers by telephone and written interviews.

Table 1 Questions for HR Experts and Managers

\begin{tabular}{|l|}
\hline What are the organiaztion's strategic goals? \\
\hline What task must be completed to achieve organizational goals? \\
\hline $\begin{array}{l}\text { What behaviors are necessary for each job holder to complete his } \\
\text { or her job duties? }\end{array}$ \\
\hline $\begin{array}{l}\text { What deficiences do job holders have in terms of skills, } \\
\text { knowledge, or abiliites required to exhibi the essential and } \\
\text { nesessary job behavors? }\end{array}$ \\
\hline $\begin{array}{l}\text { Do you think these trainings are helpful to improve individual } \\
\text { performance? If yes, please share some experiences. If not, do you } \\
\text { know what is the problem and how to solve it? }\end{array}$ \\
\hline $\begin{array}{l}\text { Do you collect and analyze training effectiveness? If yes, how do } \\
\text { you apply the results? }\end{array}$ \\
\hline
\end{tabular}

Also, researchers followed questions of Table 2 to get information of training from employees by online survey.

\begin{tabular}{|l|l|l|}
\hline \multicolumn{3}{|c|}{ Table 2 Questions for Employees } \\
\hline \multicolumn{1}{|c|}{ Questions } & Yes & No \\
\hline Is there completed individual perforance system? & & \\
\hline Is there completed employee training system? & & \\
\hline Is there only one training method used? & & \\
\hline Are there no more than 3 training methods used? & & \\
\hline Are there more than 5 training methods used? & & \\
\hline Can you complete all of your training courses? & & \\
\hline Do you think these trainings are helpful? & & \\
\hline $\begin{array}{l}\text { Does your organisation give you financial and } \\
\text { time support, when you take training programs? }\end{array}$ & & \\
\hline Can you get the training feedback timely? & & \\
\hline Do you think the feedback is useful? & & \\
\hline
\end{tabular}

According feedbacks of interviews and surveys, this research find out following five problems of training in jointequity commercial banks.

\section{A. The Imperfect Training System}

The imperfect training system is one of the training problems which is faced by joint-equity commercial banks. Since the joint-equity commercial banks cannot catch the developmental trends of finical industry, they cannot make the propriate and reasonable training plans, which cause of high training costs and low effectiveness. The imperfect training systems also decrease the competitiveness of the joint-equity commercial banks.

\section{B. Poor Training Effectiveness}

The poor training effectiveness show on following three aspects. Firstly, the training objects are not clear. Before the training courses start, most joint-equity commercial banks do not analyze job requirements and employee career planning, so the training courses and contents are useless for employees, which cause some employees unwilling to go to the training classes. HR department tried their best to push employees to present on the training courses, but most of them do their own businesses on the class. Secondly, the training contents are not systematic. Because of the impact training system, the HR department set training courses non-logically and randomly. Finally, there are no helpful and effective follow-up training courses for employees.

\section{Limited Training Methods}

The problem of the single training mode is shown on following three aspects. Firstly, most joint-equity commercial banks adopt the training method of the expert lectures, and take case study and tutorials as supplementary. They hardly provide online training sources for employees, so many employees complain that the training lectures are bored. Secondly, the fixed training schedule is not flexibility, which always occupy regular working time. Finally, since HR department of jointequity commercial banks do not analyze classes and characteristics of each job, the use the single and same mode to train employees.

\section{Insufficient Evaluation Training Outcomes}

Timely evaluating employee performance is very helpful to perfect training systems, improve training effectiveness, increase employee abilities, and develop employee talents, which are purposes of the training. However, most HR 
department of the joint-equity commercial banks delay to evaluate performance and give feedback to employees, so they cannot get information of effectiveness efficiently. Therefore, HR department of the joint-equity commercial banks cannot find the training problems and the effectiveness, and cannot improve the details of the training contents and methods, which will affect the effective conduct of the following training [2].

\section{E. Ignored Training Outcomes}

Employee training is an important module in human resource management, which is closely related to remuneration, motivation, employee promotion, and career development. However, many joint-equity commercial banks ignore the evaluation and feedback of training results, so they cannot use the training results for incenting and promoting employees. On the one hand, it reduces the significance of training results, and results information resources waste. On the other hand, the low efficiency training is neither to provide the required knowledge and skills for employees, nor to provide information supports for banks.

\section{IMPROVING THE EFFECTIVE TRAINING PATH}

The joint-equity commercial banks staff training must base on the lifelong learning system, and connects the economic and social situation with the joint-equity commercial banks' strategies, which will achieve the banks' strategic goals and personal goals at the same time. Therefore, staff training should strengthen organizational management and system construction, integrate educational training resources, and establish staff lifelong learning system and consciousness. The effective training path will provide professional talent and intellectual supports for joint-equity commercial banks, and then achieve sustainable development.

\section{A. Developing the Sense of Lifelong Learning}

For developing the sense of lifelong learning, Joint-equity commercial banks should encourage employees from following aspects. Firstly, these banks should establish the awareness of lifelong learning, and master the correct learning methods with practices. Secondly, they should solve new troubles, conflicts and problems in works to improve the professional skills and abilities. Finally, these banks will be able to create new commercial opportunities and learning atmosphere to benefit both corporates and individuals by rewarding outstanding employees and sharing information.

\section{B. Encouraging employees keep learning initiatively}

Lifelong learning theory points out that the learning process is conducted mainly by learners. Therefore, employees of banks should fully mobilize their learning initiative and enthusiasm, and actively grasp learning and developmental opportunities. First of all, employees should recognize that the training is an important channel to improve their professional abilities and competencies, and should actively participate in training. Secondly, employees should enhance their sense of mission, and cherish the training opportunities. Employees should solve problems and enrich their knowledge and skills by training to reach goals of developing both corporates and individuals. Finally, employees should consciously apply all knowledge and skills to practical work.

\section{Enriching Training Methods}

The main characteristic of lifelong learning is flexibility and diversity, so it is very helpful for enriching training methods. Firstly, HR department of joint-equity commercial banks should combine training needs with flexible and diverse traditional and new technique methods, such as asking questions, discussing, debating, stimulating situation, studying cases, the internet lectures, MOOC (Massive Open Online Course), and Flipped Classroom. These learning methods can not only initiative employees to think and participate daily learning, but also provide flexible time schedule and places to study and repeat. The flexible and diverse methods are very helpful for improve efficiency and effectiveness of training.

Secondly, the HR department of the joint-equity commercial banks also can adopt other learning methods for training, such as experiential learning and game learning, to improve abilities of finding and solving problems. These methods truly transform the training contents into changing work behavior and improving work performance.

Thirdly, the joint-equity commercial banks should take their elite departments as benchmarks. Other departments can learn from the elite departments, which can not only share learning information and methods with each other, but also save training costs. This way is very helpful to form the learning atmosphere and organizational culture.

Finally, according to the operation characteristics of each branch and the training needs of employees in different departments and levels, the joint-equity commercial banks should design training programs separately to improve the training effectiveness [3].

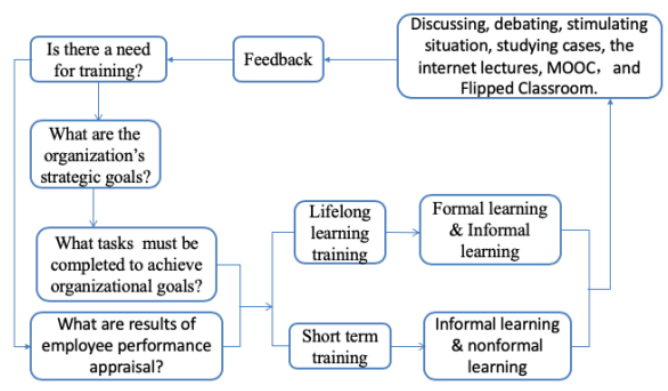

Figure1 Training System in theFigure1 Training System in the Context of Lifelong Learning

\section{Applying Training Evaluation Results}

The joint-equity commercial banks should strengthen modify and perfect the existing training plans. For promoting abilities and competencies in employee careers, banks need to continuously improves their training plans to keep training effectiveness. Firstly, they should develop evaluation criteria. Before training performance evaluation, the joint-equity commercial banks should formulate standards, and make each 
criterion specific and quantitative, which need to consider both individual needs and organizational developments. The rationality of the evaluation standards is considered as well, because it is more conducive to train performance evaluation.

Secondly, the joint-equity commercial banks should adopt reasonable evaluation methods. Different evaluation ways should be used to evaluate different training methods, because it will obtain reasonable results. For example, examinations and assignments can be used to evaluate lecture-based training, and observation also can be adopted at the same time. Besides, for evaluating online training, online learning total time can be used to evaluate the popularity degree.

Finally, the joint-equity commercial banks should timely give the evaluation results. The training and evaluation results provide further career development guidance for employees, as well as theoretical basis for enterprise salary incentive and employee promotion.

\section{CONCLUSION}

The lifelong learning is a popular and practical method, so HR department of the joint-equity commercial banks should put great efforts to develop this learning method, which will help organizations to apply training outcomes, enrich training methods, and establish training evaluation systems.

\section{ACKNOWLEDGMENT}

During the paper writing, my collogues discussed with me about this topic, and give me some good ideas. Besides, some data and information of this paper is from Pro. Xu Wang. Therefore, thanks for all helps. Also, thanks all supports of my family.

\section{REFERENCES}

[1] D. Lu, P. He, and C. Duan, "College Students Experience Career Management”. Beijing: China Machine Press, pp. 163, 2013.

[2] N. Pang, "Analysis and Countermeasures of the Current Situation of Training in Joint-equity commercial banks", Journal of Jinan Vocational College, Vol. 2, pp. 104-105, 2018.

[3] H. Xiong, and X. Chen, "Problems and Countermeasures of Enterprise Staff Training from the Perspective of Lifelong Learning", Labor Security World, Vol. 20, pp. 37, 2018. 